\title{
COPPER(II) COMPLEXES WITH NEW N-SUBSTITUTED SULFONAMIDES - SYNTHESIS, CRYSTAL STRUCTURE AND EVALUATION OF THE NUCLEASE ACTIVITY
}

\author{
ANDREEA BODOKI ${ }^{\mathrm{a},{ }^{*},}$, GLORIA ALZUET-PIÑA ${ }^{\mathrm{b}}$, \\ JOAQUÍN BORRÁS ${ }^{b}$, TAMARA TOPALÁa ${ }^{a}$, ADRIANA HANGAN ${ }^{a}$, \\ GHEORGHE BORODI ${ }^{\mathrm{c}}$, LUMINIȚA OPREAN ${ }^{\mathrm{a}}$
}

\begin{abstract}
Binary Cu(II) complexes of two new N-substituted sulfonamides, $\mathrm{N}$-(pyridin-2-yl-methyl)biphenyl-4-sulfonamide (HL1) and N-bis-(pyridin-2-ylmethyl)biphenyl-4-4'-sulfonamide $\left(\mathrm{H}_{2} \mathrm{~L} 2\right)$, have been synthesized and characterized by X-ray diffraction, spectroscopic and electrochemical techniques. The structure of complex $\left[\mathrm{Cu}(\mathrm{L} 1)_{2}\right]$ consists of a discrete monomeric $\mathrm{Cu}(\mathrm{II})$ species stabilized by $\pi-\pi$ stacking interactions involving the pyridyl and phenyl rings of the coordinated ligands. In contrast, in the case of complex $[\mathrm{Cu}(\mathrm{L} 2)] \mathrm{n}$, each symmetrical sulfonamide structure coordinates two $\mathrm{Cu}(\mathrm{II})$ ions, giving rise to a polymeric chain. Upon coordination, $\mathrm{CuN}_{4}$ chromophores with the N-pyrydil atoms in trans position are generated, and the coordination geometry of both complexes can be best described as highly distorted square-planar. The ability of complex $\left[\mathrm{Cu}(\mathrm{L} 1)_{2}\right]$ to promote DNA cleavage with ascorbate activation was also evaluated; the complex has a moderate nuclease activity, being able to partially cleave supercoiled DNA to nicked circular and linear DNA. We herein also report the evaluation of the nuclease activity of complex $\mathrm{Cu}_{2}\left(\mathrm{~N}\right.$-(pyridin-2-yl)biphenyl-4-sulfonamidate) ${ }_{4}$, previously characterized in terms of structure by our group.
\end{abstract}

Keywords: $\mathrm{Cu}(\mathrm{II})$ complexes, $\mathrm{N}$-substituted sulfonamides, $X$-ray diffraction, nuclease activity

a Department of General and Inorganic Chemistry, Faculty of Pharmacy, UMF Iuliu Hatieganu, 400010 lon Creanga, Cluj-Napoca, Romania

b Department of Inorganic Chemistry, Faculty of Pharmacy, University of Valencia, 46100 Burjassot, Valencia, Spain

c Department of Molecular and Biomolecular Service, National Institute for Research and Development for Isotopic and Molecular Technologies, 67-103 Donat, Cluj-Napoca, Romania

*Corresponding author: abota@umfcluj.ro 
ANDREEA BODOKI, GLORIA ALZUET-PIÑA, JOAQUÍN BORRÁS, TAMARA TOPALĂ, ADRIANA HANGAN, GHEORGHE BORODI, LUMINIȚA OPREAN

\section{INTRODUCTION}

In recent years there has been an increasing interest in the rational design of first row transition metal complexes with interesting features as biochemical tools and therapeutics. Substantial effort has been made during the last decades towards the development of metal complexes with a wide variety of ligand structures able to promote the degradation of nucleic acids via a hydrolytic or an oxidative mechanism [1]. To date, these synthetic nucleases are mainly employed as valuable tools for the in vitro investigation of a variety of biochemical processes, such as the investigation of the protein-DNA/RNA interactions, or of the structure of nucleic acids [2,3]. Metal complexes that target nucleic acids can also be developed as therapeutics since an effective interaction with DNA or RNA and the subsequent cleavage of nucleic acids are essential steps in the cascade of processes associated with the antitumor, antibiotic or antiviral action $[1,4]$. Although promising, the in vivo applications are without a doubt an area that needs further investigation. Issues such as low solubility, kinetic and thermodynamic liability, low substrate selectivity and efficiency, or deficient cellular delivery still need to be addressed $[1,5]$.

$\mathrm{Cu}(\mathrm{II})$, an essential metal ion, has been extensively employed as coordination center for structures with a nucleolytic potential [1,6-9] on the assumption that, in general, endogenous metals may be less toxic to normal cells and tissues. $\mathrm{Cu}(\mathrm{II})$ is versatile in terms of coordination numbers and geometries, it exhibits biologically accessible redox potentials, relatively high affinity towards nucleobases, and interesting intrinsic properties $[9,10]$.

Widely studied for their antibacterial, antidiabetic, anticancer or diuretic activity [11-14], sulfonamides are also suitable candidates for metalion coordination primarily due to the presence of $\mathrm{N}$ and $\mathrm{O}$ donor atoms in the sulfonamide moiety. $\mathrm{N}$-substitution may include functional groups with additional donor atoms; moreover, the sulfonamide structure may be designed to exhibit particular features that allow for a certain coordination pattern or that are correlated with particular desired functions of the metal complex, e.g. the inclusion of planar aromatic rings that facilitate the intercalation of the complex between the DNA base pairs. During the past decade, the remarkable oxidative nuclease activity and the antitumor properties for several $\mathrm{Cu}$ (II) complexes with $\mathrm{N}$-substituted sulfonamides have been reported [15-17].

With the aforementioned considerations in mind and as a continuation of our research [15-23], we herein report the synthesis and characterization of two new sulfonamide derivatives, $\mathrm{N}$-(pyridin-2-yl-methyl)biphenyl-4-sulfonamide (HL1) and N-bis-(pyridin-2-yl-methyl)biphenyl-4-4'-sulfonamide $\left(\mathrm{H}_{2} \mathrm{~L} 2\right)$ (Scheme 1). The $\mathrm{Cu}(\mathrm{II})$ complexes of these ligands, $\left[\mathrm{Cu}(\mathrm{L} 1)_{2}\right]$ and $[\mathrm{Cu}(\mathrm{L} 2)]_{n}$ were structurally 
COPPER(II) COMPLEXES WITH NEW N-SUBSTITUTED SULFONAMIDES - SYNTHESIS, CRYSTAL STRUCTURE AND EVALUATION OF THE NUCLEASE ACTIVITY

characterized and the nuclease potential of complex $\left[\mathrm{Cu}(\mathrm{L} 1)_{2}\right]$ was evaluated. The nuclease activity of the dinuclear complex $\mathrm{Cu}_{2}(\mathrm{~N}$-(pyridin-2-yl)biphenyl4-sulfonamidate) $)_{4}$, structurally characterized in our previous work [24], is also herein reported and compared with that of $\left[\mathrm{Cu}(\mathrm{L} 1)_{2}\right]$.

\section{RESULTS AND DISCUSSION}

The $\mathrm{HL}_{1}$ and $\mathrm{H}_{2} \mathrm{~L} 2$ ligands were prepared according to Scheme 1.
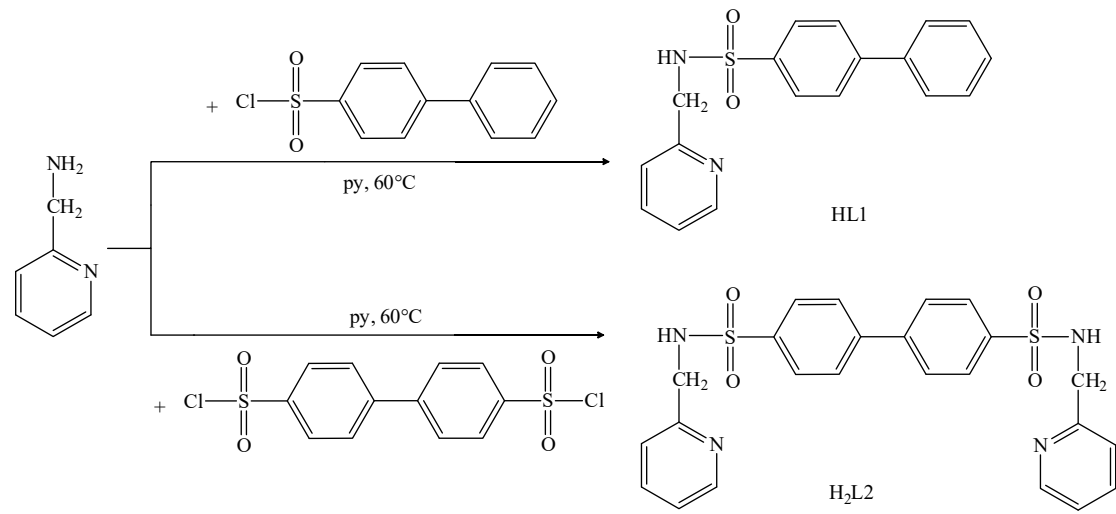

Scheme 1. Synthesis of ligands N-(pyridin-2-yl-methyl)biphenyl-4-sulfonamide (HL1) and N-bis-(pyridin-2-yl-methyl)biphenyl-4-4'-sulfonamide $\left(\mathrm{H}_{2} \mathrm{~L} 2\right)$

Complex $\left[\mathrm{Cu}(\mathrm{L} 1)_{2}\right]$ is readily soluble in N,N-dimethylformamide (DMF) and showed low solubility in aqueous media. Complex $[\mathrm{Cu}(\mathrm{L} 2)]_{\mathrm{n}}$ however showed very low solubility in all solvents compatible with biological media.

\section{X-ray crystallography}

The molecular structures of complexes $\left[\mathrm{Cu}(\mathrm{L} 1)_{2}\right]$ and $[\mathrm{Cu}(\mathrm{L} 2)]_{n}$ together with the atomic labeling scheme are shown in Figures 1 and 2 . The relevant structural parameters for the complexes are listed in Table 1.

The monodeprotonated structure $\mathrm{L}^{-}$- and the double deprotonated symmetric ligand $\mathrm{L}^{2-}$ both coordinate the $\mathrm{Cu}(\mathrm{II})$ ions through the pyridyl and the sulfonamide nitrogen atoms.

Upon coordination, $\mathrm{CuN}_{4}$ chromophores with the $\mathrm{N}$-pyrydil atoms in trans position are generated for both binary complexes. Tetrahedrality estimated from the angle subtended by two planes, each encompassing $\mathrm{Cu}(\mathrm{II})$ and two donor atoms [25], is of $33.81^{\circ}$ for complex [Cu(L1) 2 ] and of $46.63^{\circ}$ for complex $[\mathrm{Cu}(\mathrm{L} 2)]_{\mathrm{n}}$. The calculated tetrahedrality suggest an important distortion from the strict square-planar geometry for complex $\left[\mathrm{Cu}(\mathrm{L} 1)_{2}\right]$, while for complex 
$[\mathrm{Cu}(\mathrm{L} 2)]_{\mathrm{n}}$ it indicates that the local environment around the $\mathrm{Cu}(\mathrm{II})$ ion is mid-way between tetrahedral and square-planar. For four-coordinate $\mathrm{Cu}(\mathrm{II})$ complexes the distortion from ideal square-planar or tetrahedral geometries can be evaluated by the index $T_{4}$ ranging from 1 , for perfect tetrahedral, to zero, for perfect square-planar geometry [26]. The $\mathrm{T}_{4}$ value of 0.36 for complex [Cu(L1) $)_{2}$ and 0.42 for complex [Cu(L2)]n indicate highly distorted square-planar geometries.

The coordination polyhedron of complex $\left[\mathrm{Cu}(\mathrm{L} 1)_{2}\right]$ exhibits features similar to those reported for other $\mathrm{Cu}(\mathrm{II})$ complexes with 2-aminomethylpyridine derivatives as ligands [27-29]. The $\mathrm{Cu}-\mathrm{N}_{\text {sulfonamido }}$ bond lengths, of 1.930(2) $\AA$ and $1.965(2) \AA$, are slightly shorter than the Cu- $\mathrm{N}_{\text {pyridyl }}$ ones $(1.988(2) \AA$ and $1.992(2) \AA)$. The bond angles formed by the central ion and the nitrogen atoms belonging to the same ligand structure (close to $83^{\circ}$ ) are smaller than those formed by the $\mathrm{Cu}(\mathrm{II})$ ion with the nitrogen atoms from the two distinct ligands in the coordination environment, especially with the nitrogen atoms adjacent to the sulfonyl group, probably because of the steric hindrance between these moieties [27].

For the polymeric complex $[\mathrm{Cu}(\mathrm{L} 2)]_{\mathrm{n}}$, the $\mathrm{Cu}-\mathrm{N}$ bond lengths are of $1.992(7) \AA$ for the $\mathrm{Cu}-\mathrm{N}_{\text {pyridyl }}$ bonds and of $1.916(8) \AA$ for the $\mathrm{Cu}-\mathrm{N}_{\text {sufonamido }}$ bonds, within the expected range for $\mathrm{Cu}$ (II) complexes with similar ligands [23, 24, 27, 30-32]. The N-Cu-N angles that describe the coordination polyhedron, of $82.7(4)^{\circ}$ and $103.8(4)^{\circ}$, deviate significantly from $90^{\circ}$. As it is to be expected, the smaller angles, of $82.7(4)^{\circ}$, correspond to those formed by $\mathrm{Cu}(\mathrm{II})$ and two nitrogen atoms belonging to the same ligand structure, because of strains induced by the sulfonamide molecule itself. The $\mathrm{Cu}-\mathrm{N}_{\text {pyridyl }}$ bond distances are very similar in the two complexes, while the $\mathrm{Cu}-\mathrm{N}_{\text {sulfonamido }}$ distances in complex $[\mathrm{Cu}(\mathrm{L} 2)]_{\mathrm{n}}$ are slightly shorter than the analogous ones in complex $\left[\mathrm{Cu}(\mathrm{L} 1)_{2}\right]$. Also, the bond angles $\mathrm{N}_{\text {sulfonamido }}-\mathrm{Cu}-\mathrm{N}_{\text {pyridyl }}$ are of close values in the case of both complexes.

Table 1. Selected bond lengths $(\AA)$ and angles $\left(^{\circ}\right)$ for complexes

$\left[\mathrm{Cu}(\mathrm{L} 1)_{2}\right]$ and $[\mathrm{Cu}(\mathrm{L} 2)] \mathrm{n}$

\begin{tabular}{|lc|lr|}
\hline$\left[\mathrm{Cu}(\mathrm{L} 1)_{2}\right]$ & & {$[\mathrm{Cu}(\mathrm{L} 2)]_{\mathrm{n}}$} & \\
\hline $\mathrm{Cu}(1)-\mathrm{N}(2)$ & $1.930(2)$ & $\mathrm{Cu}(1)-\mathrm{N}(3)$ & $1.916(8)$ \\
$\mathrm{Cu}(1)-\mathrm{N}(4)$ & $1.965(2)$ & $\mathrm{Cu}(1)-\mathrm{N}(3)^{1}$ & $1.916(8)$ \\
$\mathrm{Cu}(1)-\mathrm{N}(3)$ & $1.988(2)$ & $\mathrm{Cu}(1)-\mathrm{N}(4)$ & $1.992(7)$ \\
$\mathrm{Cu}(1)-\mathrm{N}(1)$ & $1.992(2)$ & $\mathrm{Cu}(1)-\mathrm{N}(4)^{1}$ & $1.992(7)$ \\
$\mathrm{N}(2)-\mathrm{Cu}(1)-\mathrm{N}(4)$ & $157.87(10)$ & $\mathrm{N}(3)-\mathrm{Cu}(1)-\mathrm{N}(3)^{1}$ & $159.4(6)$ \\
$\mathrm{N}(2)-\mathrm{Cu}(1)-\mathrm{N}(3)$ & $102.04(9)$ & $\mathrm{N}(3)-\mathrm{Cu}(1)-\mathrm{N}(4)$ & $82.7(4)$ \\
$\mathrm{N}(4)-\mathrm{Cu}(1)-\mathrm{N}(3)$ & $83.48(9)$ & $\mathrm{N}(3)^{1}-\mathrm{Cu}(1)-\mathrm{N}(4)$ & $103.8(4)$ \\
$\mathrm{N}(2)-\mathrm{Cu}(1)-\mathrm{N}(1)$ & $83.23(9)$ & $\mathrm{N}(3)-\mathrm{Cu}(1)-\mathrm{N}(4)^{1}$ & $103.8(4)$ \\
$\mathrm{N}(4)-\mathrm{Cu}(1)-\mathrm{N}(1)$ & $102.59(9)$ & $\mathrm{N}(3)^{1}-\mathrm{Cu}(1)-\mathrm{N}(4)^{1}$ & $82.7(4)$ \\
$\mathrm{N}(3)-\mathrm{Cu}(1)-\mathrm{N}(1)$ & $150.52(9)$ & $\mathrm{N}(4)-\mathrm{Cu}(1)-\mathrm{N}(4)^{1}$ & $144.1(5)$ \\
\hline
\end{tabular}

Symmetry transformations used to generate equivalent atoms: ${ }^{1} 1-\mathrm{X},+\mathrm{Y}, 1 / 2-\mathrm{Z}$ 
The structure of complex [Cu(L1) $]$ consists of a discrete monomeric $\mathrm{Cu}$ (II) species stabilized by $\Pi-\pi$ stacking interactions involving the aromatic rings of the coordinated ligands (Figure 3 ). Interestingly, the monomeric nature of complex $\left[\mathrm{Cu}(\mathrm{L} 1)_{2}\right]$ contrasts with the dimeric one exhibited by the previously reported complex $\mathrm{Cu}_{2}(\mathrm{~N} \text {-(pyridin-2-yl)biphenyl-4-sulfonamidate })_{4}$ [24] obtained with a ligand similar to HL1. As a tentative, this different nature could be attributed to the presence in $\mathrm{HL} 1$ of a $\mathrm{CH}_{2}$ group linking the pyridine ring and the sulfonamide group that prevents in $[\mathrm{Cu}(\mathrm{L} 1)]_{\mathrm{n}}$ the formation of a $\mathrm{NCN}$ bridge found in other stable dinuclear and tetranuclear $\mathrm{Cu}(\mathrm{II})$ compounds with sulfonamide derivatives as ligands [33,34]. A polymeric chain is generated in the case of complex [Cu(L2)]n (Figure 4), where two adjacent $\mathrm{Cu}(\mathrm{II})$ ions are separated by a distance of $13.48 \AA$; one $\mathrm{N}_{\text {pyrydil }}(\mathrm{N} 4$ and N4\#1) and one $\mathrm{N}_{\text {sulfonamido }}$ (N3 and N3\#1) atoms coordinate one metallic center, while the other two nitrogen atoms of the symmetric ligand structure coordinates a second $\mathrm{Cu}(\mathrm{II})$ ion.

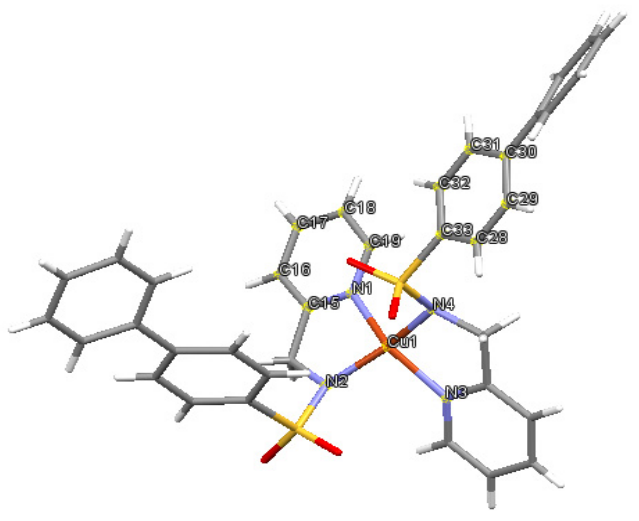

Figure 1. Molecular structure of complex $\left[\mathrm{Cu}(\mathrm{L} 1)_{2}\right]$

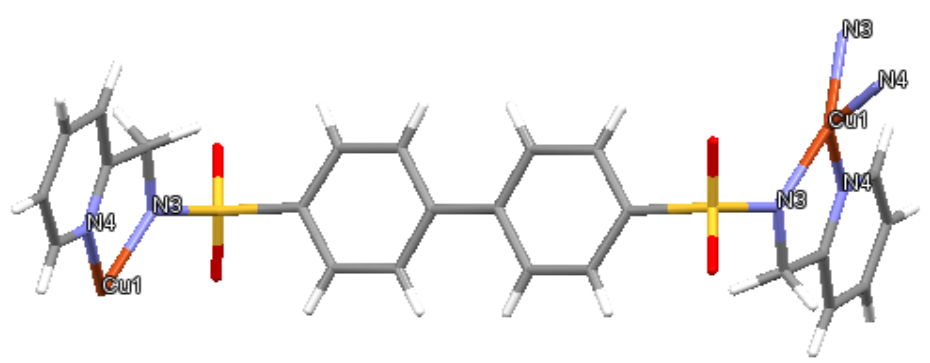

Figure 2. Molecular structure of complex [Cu(L2)]n 
The structure of complex $\left[\mathrm{Cu}(\mathrm{L} 1)_{2}\right]$ is stabilized by two types of moderate strength $\pi-\pi$ interactions determined by the pyridyl-pyridyl and phenyl-pyridyl parallel stacking of the rings belonging to adjacent complex molecules. The structural parameters defining these interactions are listed in Table 2. Interactions that implied centroid-centroid distances, $\mathrm{d}(\perp \mathrm{C}(\mathrm{J})-\mathrm{C}(\mathrm{I}))$, of less than $6 \AA$ and $\beta<60^{\circ}$ were investigated. The distances between the interacting centroids is approximately $3.8 \AA$, close to the maximum at which $\pi-\pi$ interactions occur [35]. The value of $0.02^{\circ}$ of the dihedral angle $\alpha$ characterizing the pyridyl-phenyl interactions indicates a close parallelism between these interacting rings. An accentuated deviation from parallelism occurs for the pyridyl-pyridyl interaction $\left(\alpha=11.97^{\circ}\right)$, suggesting a rather pronounced slipping of the interacting centroids, similar to that reported for the dimeric complex $\mathrm{Cu}_{2}(\mathrm{~N}$-(pyridine-2-yl)biphenyl4-sulfonamidate $)_{4}$ [24]. A representation of the crystal packing of complex $\left[\mathrm{Cu}(\mathrm{L} 1)_{2}\right]$ showing the pyridyl-phenyl $\pi-\pi$ interactions is shown in Figure 3.

Table 2. Geometric parameters for $\pi-\pi$ stacking $\left[\AA /{ }^{\circ}\right]$ in complex $\left[\mathrm{Cu}(\mathrm{L} 1)_{2}\right]$

\begin{tabular}{|c|c|c|c|c|c|c|}
\hline$\pi-\pi$ stacking & $\mathrm{dc}_{\mathrm{c}-\mathrm{c}}$ & $\alpha$ & $\beta$ & Y & $\mathrm{d}_{\perp}[\mathrm{Cg}(\mathrm{I})-\mathrm{P}(\mathrm{J})]$ & $d_{\perp}[C g(J)-P(I)]$ \\
\hline \multicolumn{7}{|l|}{ Pyridyl-pyridyl } \\
\hline $\mathrm{Cg}(3)-\mathrm{Cg}(3)^{\mathrm{a}}$ & 3.842 & 0.02 & 20.12 & 20.12 & 3.608 & 3.608 \\
\hline \multicolumn{7}{|l|}{ Pyridyl-phenyl } \\
\hline $\mathrm{Cg}(3)-\mathrm{Cg}(7)^{\mathrm{b}}$ & 3.841 & 11.97 & 23.19 & 13.15 & 3.741 & 3.531 \\
\hline
\end{tabular}

dc-c: distance between ring centroids; $\alpha$ : dihedral angle between the rings; $\beta, \mathrm{y}$ : slipping angles; $d \perp[C g(I)-P(J)]$ and $d \perp[C g(J)-P(I)]$ : centroid $C g(I)$ to plane $J$ distance and the opposite. a) $-\mathrm{x}, 1-\mathrm{y},-\mathrm{z}$ b) $\mathrm{x}, 1+\mathrm{y}, \mathrm{z}$. Cg(3): N1-C15-C16-C17-C18-C19; $\mathrm{Cg}(7)$ : C28-C29-C30-C31-C32-C33

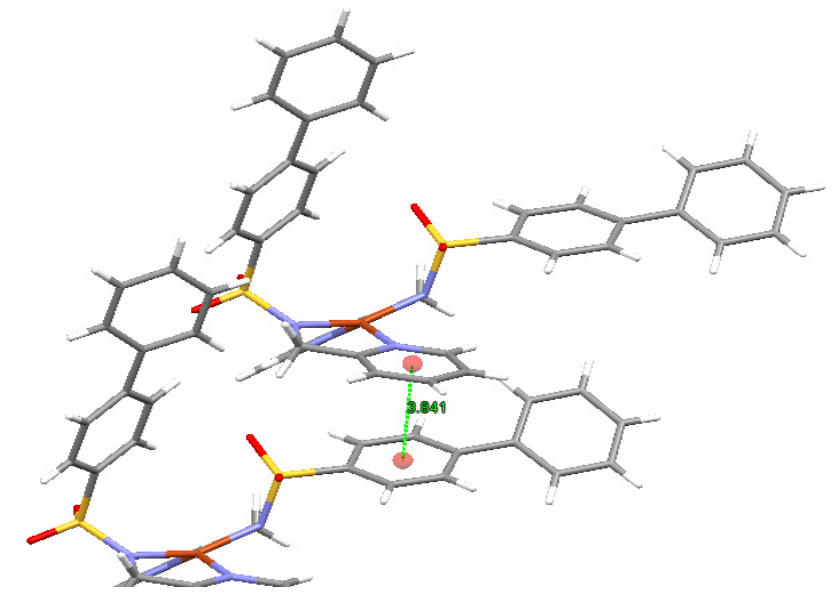

Figure 3. Crystal packing of complex $\left[\mathrm{Cu}(\mathrm{L} 1)_{2}\right]$ showing the pyridyl-phenyl stacking interactions 


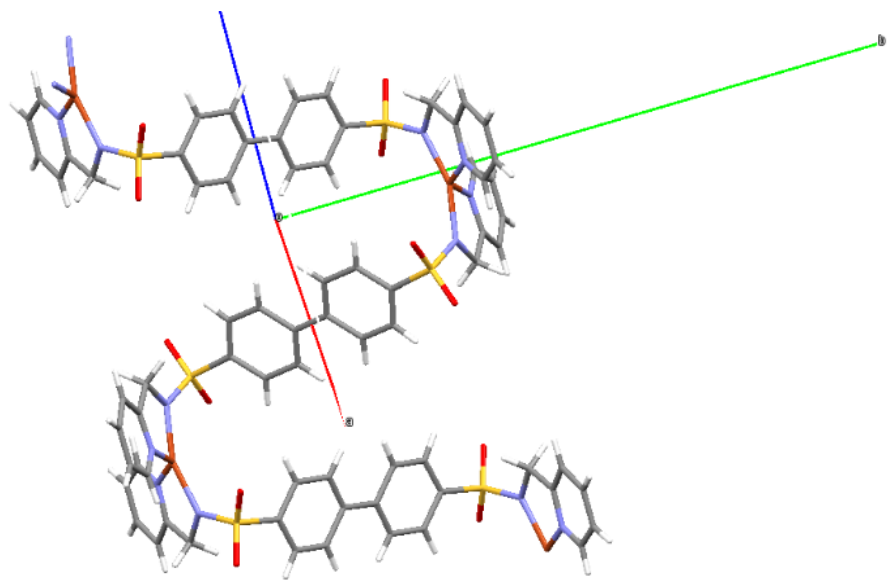

Figure 4. Polymer chain formation for complex $[\mathrm{Cu}(\mathrm{L} 2)] \mathrm{n}$ along the crystallographic $\mathrm{c}$ axis

\section{Spectroscopic properties}

Complexes $\left[\mathrm{Cu}(\mathrm{L} 1)_{2}\right]$ and $[\mathrm{Cu}(\mathrm{L} 2)]_{\mathrm{n}}$ exhibit the same infrared spectrum pattern, similar to that observed for other $\mathrm{Cu}(\mathrm{II})$ complexes with $\mathrm{N}$ substituted sulfonamides $[15,23,24,28,36]$. As a consequence of the involvement of the sulfonamide moiety in the coordination of the metal center and its deprotonation, the band assigned to the $\mathrm{N}-\mathrm{H}$ stretching vibration disappears, and the bands assigned to $\mathrm{v}_{\text {sym }}\left(\mathrm{SO}_{2}\right), \mathrm{v}_{\text {asym }}\left(\mathrm{SO}_{2}\right)$ and $\mathrm{v}(\mathrm{S}-\mathrm{N})$ appear shifted in the IR spectra of both complexes. Thus, the band assigned to the $v_{\text {asym }}\left(\mathrm{SO}_{2}\right)$ is shifted towards lower frequencies, while the $v_{\text {sym }}\left(\mathrm{SO}_{2}\right)$ is shifted towards higher frequencies for $\left[\mathrm{Cu}\left(\mathrm{L}_{1}\right)_{2}\right]$ and towards lower frequencies for $[\mathrm{Cu}(\mathrm{L} 2)]_{\mathrm{n}}$. The band assigned to the vibrations of the S-N bond appears shifted towards higher frequencies in both cases. The bands corresponding to the stretching vibrations of the pyridyl ring $(\mathrm{v}(\mathrm{C}=\mathrm{N})$ and $\mathrm{v}(\mathrm{C}=\mathrm{C}))$ are also slightly shifted as a result of metal ion coordination.

The diffuse reflectance spectra of both complexes exhibit a broad asymmetric band centred at $615 \mathrm{~nm}$ for $\left[\mathrm{Cu}(\mathrm{L} 1)_{2}\right]$ and at $595 \mathrm{~nm}$ for $[\mathrm{Cu}(\mathrm{L} 2)]_{\mathrm{n}}$. These bands correspond to the ligand field transitions characteristic of distorted square-planar complexes with $\mathrm{CuN}_{4}$ chromophores [29]. The $\mathrm{d}-\mathrm{d}$ band in the spectrum of complex $\left[\mathrm{Cu}(\mathrm{L} 1)_{2}\right]$ recorded in DMF solution appears centred at $625 \mathrm{~nm}$; this shift is most likely a consequence of the intervention of the solvent. The results are in agreement with the data from the ESI experiments which reveal that a $\mathrm{Cu}(\mathrm{II})$ and two sulfonamide ligands exist as an entity in DMF solution. 
The EPR spectrum of complex $\left[\mathrm{Cu}(\mathrm{L} 1)_{2}\right]$ is slightly rhombic. The simulated EPR parameters [37] are $g_{x}=2.04, g_{y}=2.052$ and $g_{z}=2.228$. The ratio $R=\left(g_{y}-g_{x}\right) /\left(g_{z}-g_{y}\right)$, calculated for rhombic systems with $g_{z}>g_{y}>g_{x}$, has a value of 0.07 indicating that the unpaired electron of $\mathrm{Cu}(\mathrm{II})$ is placed mainly in the $d_{x 2-y 2}$ orbital [38]. Complex $[\mathrm{Cu}(\mathrm{L} 2)]_{\mathrm{n}}$ exhibits an axial EPR spectrum with the following simulated parameters: $g_{\|}=2.230$ and $g_{\perp}=2.062$. The values $g_{\|}>g_{\perp}$ are indicative of a mainly $\mathrm{Cu}(\mathrm{II}) \mathrm{d}_{\mathrm{x} 2 \mathrm{-y} 2}$ ground state.

\section{Cyclic voltammetry experiments}

The electrochemical profile of complex $\left[\mathrm{Cu}(\mathrm{L} 1)_{2}\right]$ was studied in DMF by cyclic voltammetry in the range 1.0 to $-1.0 \mathrm{~V}$. The voltammogram shows one cathodic peak at $-0.212 \mathrm{~V}$, indicating an irreversible redox process suggesting that the $\mathrm{Cu}(\mathrm{II})$ species decomposes at higher potential.

\section{DNA cleavage}

The ability of complex [Cu(L1) 2 ] to cleave double-stranded DNA was evaluated by gel electrophoresis on supercoiled plasmid DNA (pUC18), in $0.05 \mathrm{M}$ borate buffer $(\mathrm{pH}=8.0)$ using sodium ascorbate as activating agent and complex concentration in the range $3-12 \mu \mathrm{M}$. A sample containing pUC18 plasmid DNA in the presence of $12 \mu \mathrm{M} \mathrm{Cu}(\mathrm{II})$ ions was also run as control experiment. For comparison reasons, and on the premises that multiple metal centres may exhibit synergistic effects in DNA recognition and cleavage $[39,40]$, we have also examined the nuclease activity of the related dimeric compound $\mathrm{Cu}_{2}(\mathrm{~N} \text {-(pyridin-2-yl)biphenyl-4-sulfonamidate })_{4}$ [24], under the same experimental conditions.

The electrophoresis (Figure 5) shows that most of the pUC18 plasmid DNA remains in the supercoiled conformation in the entire range of the assayed complexes concentrations (Figure 5, lanes $4-7$ for complex $\left[\mathrm{Cu}(\mathrm{L} 1)_{2}\right]$ and lanes $8-11$ for complex $\mathrm{Cu}_{2}(\mathrm{~N}$-(pyridin-2-yl)biphenyl-4sulfonamidate $)_{4}$ ). The maximum assayed concentration of complex $\left[\mathrm{Cu}(\mathrm{L} 1)_{2}\right]$ $(12 \mu \mathrm{M})$ induces however the partial transformation of supercoiled DNA into nicked and linear forms (Figure 5, lane 7), suggesting that complex [Cu(L1) 2$]$ is a moderate chemical nuclease. Unfortunately, despite the presence of two $\mathrm{Cu}(\mathrm{II})$ ions per complex unit, $\mathrm{Cu}_{2}\left(\mathrm{~N}\right.$-(pyridin-2-yl)biphenyl-4-sulfonamidate) ${ }_{4}$ was not able to induce DNA cleavage (Figure 5, lanes $8-11$ ). The lack of nuclease activity of this dinuclear compound could be attributed to its high redox stability that avoids the formation of $\mathrm{Cu}(\mathrm{I})$ species (24). 
COPPER(II) COMPLEXES WITH NEW N-SUBSTITUTED SULFONAMIDES - SYNTHESIS, CRYSTAL STRUCTURE AND EVALUATION OF THE NUCLEASE ACTIVITY

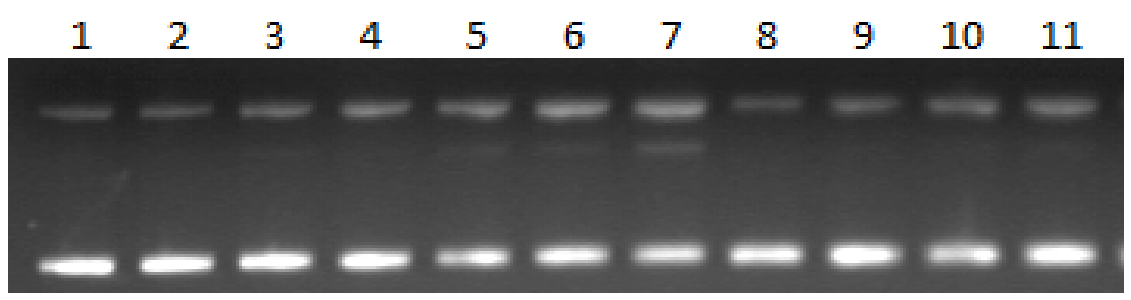

Figure 5. Agarose gel electrophoresis of pUC18 DNA in the presence of complex $\left[\mathrm{Cu}(\mathrm{L} 1)_{2}\right]$ with ascorbate activation. Incubation time: $1 \mathrm{~h}\left(37^{\circ} \mathrm{C}\right)$. Lane 1: pUC18; lane 2: pUC18 + 12mM ascorbate; lane 3: $12 \mu \mathrm{M} \mathrm{CuCl}_{2}+12 \mathrm{mM}$ ascorbate; lanes $4-7$ : 3, 6, $912 \mu \mathrm{M}\left[\mathrm{Cu}(\mathrm{L} 1)_{2}\right]+3,6,9,12 \mathrm{mM}$ ascorbate, respectively; lanes $8-11: 3,6$, 9, $12 \mu \mathrm{M} \mathrm{Cu}_{2}(\mathrm{~N} \text {-(pyridin-2-yl)biphenyl-4-sulfonamidate) })_{4}+3,6,9,12 \mathrm{mM}$ ascorbate, respectively

The polymeric $[\mathrm{Cu}(\mathrm{L} 2)]_{\mathrm{n}}$ is poorly soluble in solvent systems that are compatible with biological media, and therefore its nucleolytic potential was not evaluated at this stage. However, surface adhesion in micelles or entrapment of $\mathrm{Cu}(\mathrm{II})$ complexes into polymeric nanoparticles are proven to address the solubility and the stability problems related to numerous $\mathrm{Cu}$ (II) complexes [1, 41]. A similar approach is envisaged for the complex reported herein as a way to evaluate its nucleolytic potential.

\section{CONCLUSIONS}

Two new N-substituted sulfonamides, N-(pyridin-2-yl-methyl)biphenyl-4sulfonamide (HL1) and N-bis-(pyridin-2-yl-methyl)biphenyl-4-4'-sulfonamide $\left(\mathrm{H}_{2} \mathrm{~L} 2\right)$ and their binary $\mathrm{Cu}(\mathrm{II})$ complexes, $\left[\mathrm{Cu}(\mathrm{L} 1)_{2}\right]$ and $[\mathrm{Cu}(\mathrm{L} 2)]_{n}$, have been synthesized and structurally and physicochemically characterized. Both ligands coordinate the $\mathrm{Cu}(\mathrm{II})$ ions through the pyridyl and the sulfonamide nitrogen atoms, but the monodeprotonated L1- ligand gives rise to a discrete monomeric $\mathrm{Cu}(\mathrm{II})$ species $\left[\mathrm{Cu}(\mathrm{L} 1)_{2}\right]$, while the symmetrical $\mathrm{L}^{2-}$ coordinates $\mathrm{Cu}(\mathrm{II})$ ions to create a polymeric chain. Complex $\left[\mathrm{Cu}(\mathrm{L} 1)_{2}\right]$ exhibits a nuclease activity of moderate intensity upon ascorbate activation and at concentration of $12 \mu \mathrm{M}$. The related dinuclear $\mathrm{Cu}_{2}(\mathrm{~N}$-(pyridin-2-yl)biphenyl4-sulfonamidate $)_{4}$ is not able to cleave DNA, a fact that could be related to the high redox stability of the compound. The nuclease activity of complex $[\mathrm{Cu}(\mathrm{L} 2)]_{n}$ could not be evaluated at this stage, due to its low solubility. 
ANDREEA BODOKI, GLORIA ALZUET-PIÑA, JOAQUÍN BORRÁS, TAMARA TOPALĂ, ADRIANA HANGAN, GHEORGHE BORODI, LUMINITTA OPREAN

\section{EXPERIMENTAL SECTION}

\section{Materials and physical measurements}

All reagents and solvents were commercially available and were used without further purification.

Elemental analyses were performed on a Carlo Erba AAS instrument. NMR spectra $\left({ }^{1} \mathrm{H},{ }^{13} \mathrm{C}, \mathrm{HSQC}\right.$ and $\left.\mathrm{COSY}\right)$ were recorded on an Advancer DRX 300 Bruker $(500 \mathrm{MHz})$ instrument. The solvent used was deuterated dimethylsulfoxide (DMSO). Chemical shifts are reported relative to the residual $d_{6}$-DMSO $\left(\delta_{\mathrm{H}} 2.50 \mathrm{ppm}\right.$ and $\left.\delta_{\mathrm{C}} 39.43 \mathrm{ppm}\right)$. IR spectra were recorded using a Jasco FT-IR 4100 instrument equipped with a ZnSe ATR crystal, in the $4000-650 \mathrm{~cm}^{-1}$ spectral range. UV-Vis spectra in solution and diffuse reflectance electronic spectra were recorded on a Jasco V-550 spectrophotometer in the range 200-800 $\mathrm{nm}$. Electrospray ionization mass spectra (positive mode) analyses were performed on a Bruker Esquire 3000 plus Ion Trap Spectrometer coupled with an Agilent 1100 Chemstation liquid chromatography-mass spectrometry system. Electronic Paramagnetic Resonance (EPR) spectra were collected with a Bruker ELEXSYS spectrometer. Cyclic voltammetry experiments were performed in a single compartment cell with a three-electrode system on a PAR 273A potentiostat/galvanostat. The working and auxiliary electrode were platinum, and the reference electrode was $\mathrm{Ag} / \mathrm{AgCl}$. The supporting electrolyte was tetrabutylammonium perchlorate.

Synthesis of $\mathrm{N}$-(pyridin-2-yl-methyl)biphenyl-4-sulfonamide (HL1) and $\mathbf{N}$-bis-(pyridin-2-yl-methyl)biphenyl-4-4'-sulfonamide $\left(\mathrm{H}_{2} \mathrm{~L} 2\right)$

Solutions containing $2 \mathrm{~g}(7.9 \mathrm{mmol})$ of biphenyl-4-sulfonyl chloride (for HL1) or $2 \mathrm{~g}$ (5.7 mmol) of biphenyl-4,4'-disulfonyl chloride (for $\mathrm{H}_{2} \mathrm{~L} 2$ ) and the corresponding quantity of 2-aminomethylpyridine, $0.85 \mathrm{~g}(7.9 \mathrm{mmol})$ for $\mathrm{HL} 1$ and $1.23 \mathrm{~g}(11.4 \mathrm{mmol})$ for $\mathrm{H}_{2} \mathrm{~L} 2$, in $6 \mathrm{~mL}$ of pyridine were heated at $60^{\circ} \mathrm{C}$ for $4 \mathrm{~h}$. By quenching with $50 \mathrm{~mL}$ of cold water, white-cream solids formed in the reaction mixtures and the suspensions were further stirred for additional $30 \mathrm{~min}$ at $0^{\circ} \mathrm{C}$. The resulting solids were washed with cold water and ethanol at $60^{\circ} \mathrm{C}$.

Data for $\mathrm{HL1}-\mathrm{C}_{18} \mathrm{H}_{16} \mathrm{~N}_{2} \mathrm{SO}_{2}$ (MW = 324.40): calculated (found) C, 66.65 (67.08); H, 4.97 (5.04); N, 8.64 (8.45); S, 9.88 (9.68) \%. ${ }^{1} \mathrm{H}$ NMR (300 $\mathrm{MHz}$ ) (DMSO-d,$\delta / \mathrm{ppm}): 8.44[1 \mathrm{H}, \mathrm{d}, \mathrm{J}=4.3, \mathrm{H}$ pyridine]; $8.37[1 \mathrm{H}, \mathrm{t}, \mathrm{J}=6.3$, $\mathrm{NH}$ ]; $7.85[4 \mathrm{H}, \mathrm{s}, \mathrm{H}$ - biphenyl]; 7.7 [3H, m, H biphenyl, $\mathrm{H}$ pyridine], $7.5[2 \mathrm{H}$, pseudo-t, $\mathrm{H}$ biphenyl]; 7.45 [1 $\mathrm{H}, \mathrm{d}, \mathrm{J}=6.9, \mathrm{H}$ biphenyl]; $7.4[1 \mathrm{H}, \mathrm{d}, \mathrm{J}=7.8, \mathrm{H}$ pyridine]; $7.25[1 \mathrm{H}, \mathrm{t}, \mathrm{J}=6.3, \mathrm{H}$ pyridine $] ; 4.1\left(2 \mathrm{H}, \mathrm{d}, \mathrm{J}=6.3, \mathrm{CH}_{2}\right] .{ }^{13} \mathrm{C} \mathrm{NMR}$ 
COPPER(II) COMPLEXES WITH NEW N-SUBSTITUTED SULFONAMIDES - SYNTHESIS, CRYSTAL STRUCTURE AND EVALUATION OF THE NUCLEASE ACTIVITY

(300 MHz) (d $\mathrm{d}_{6}$-DMSO, $\left./ \mathrm{ppm}\right): 156.9,148.4,138.5,122.4,121.7$ (C pyridine); 143.8, 139.2, 136.9, 129.1, 128.4, 127.2, 127.1, 127.0 (C phenyl); $47.8\left(\mathrm{CH}_{2}\right)$. IR (ATR) $\left(\mathrm{v}_{\max } / \mathrm{cm}^{-1}\right): 3066 \mathrm{v}(\mathrm{N}-\mathrm{H}) ; 1333 \mathrm{v}_{\text {asym }}\left(\mathrm{SO}_{2}\right) ; 1166 \mathrm{v}_{\text {sym }}\left(\mathrm{SO}_{2}\right), 944 \mathrm{v}(\mathrm{S}-\mathrm{N})$. $\mathrm{ESI}^{+}$(DMF): $m / z^{+} 325$.

Data for $\mathrm{H}_{2} \mathrm{~L} 2-\mathrm{C}_{24} \mathrm{H}_{22} \mathrm{~N}_{4} \mathrm{~S}_{2} \mathrm{O}_{4}(\mathrm{MW}=494.59)$ : calculated (found) $\mathrm{C}$, 58.28 (58.13); H, 4.48 (4.53); N, 11.33 (11.05); S, 12.96 (13.11) \%. ${ }^{1} \mathrm{H}$ NMR $(300 \mathrm{MHz})\left(\mathrm{d}_{6}-\mathrm{DMSO}, \mathrm{\delta} / \mathrm{ppm}\right): 8.4$ [2H, t, NH, H pyridine]; 7.9 [4H, s, phenyl]; $7.8[1 \mathrm{H}, \mathrm{dt}, \mathrm{H}$ pyridine]; $7.4[1 \mathrm{H}, \mathrm{d}, \mathrm{J}=7.9 \mathrm{~Hz}, \mathrm{H}$ pyridine]; $7.3[1 \mathrm{H}, \mathrm{t}, \mathrm{J}=5.8, \mathrm{H}$ pyridine]; $4.2\left[2 \mathrm{H}, \mathrm{d}, \mathrm{J}=6.3, \mathrm{CH}_{2}\right] .{ }^{13} \mathrm{C}$ NMR $(300 \mathrm{MHz})\left(\mathrm{d}_{6}-\mathrm{DMSO}, \delta / \mathrm{ppm}\right)$ : 156.7, 142.2, 140.1 (C phenyl, C pyridine); 148.2, 137.3, 122.6, 121.9 (C pyridine); 127.8, 127.3 (C phenyl); $47.6\left(\mathrm{CH}_{2}\right)$. IR (ATR) $\left(\mathrm{V}_{\max } / \mathrm{cm}-1\right): 3030$ $\mathrm{v}(\mathrm{N}-\mathrm{H}) ; 1333 \mathrm{vasym}\left(\mathrm{SO}_{2}\right) ; 1155 \mathrm{v}_{\text {sym }}\left(\mathrm{SO}_{2}\right), 944 \mathrm{v}(\mathrm{S}-\mathrm{N})$. $\mathrm{ESI}^{+}(\mathrm{DMF}): \mathrm{m} / \mathrm{z}^{+} 495$.

\section{Synthesis of complex [Cu(L1) $]$}

A solution of $0.5 \mathrm{mmol} \mathrm{HL} 1(162.2 \mathrm{mg})$ in $10 \mathrm{~mL}$ of a pyridine: $\mathrm{H}_{2} \mathrm{O}$ mixture $(1: 1 \mathrm{v} / \mathrm{v})$ was added dropwise to a solution of $0.5 \mathrm{mmol} \mathrm{CuSO}_{4} \cdot 5 \mathrm{H}_{2} \mathrm{O}$ $(124.85 \mathrm{mg}$ ) in $10 \mathrm{~mL}$ of the same solvent mixture. The resulting dark-blue solution was stirred for $1 \mathrm{~h}$ and left to stand at room temperature. Within several days, blue plate $\mathrm{Cu}(\mathrm{II})$ complex monocrystals suitable for X-ray diffraction formed in the solution. The crystals were separated by means of filtration, washed with methanol and dried under vacuum.

Data for $\left[\mathrm{Cu}(\mathrm{L} 1)_{2}\right]$ Anal. for $\mathrm{CuC}_{36} \mathrm{H}_{30} \mathrm{~N}_{4} \mathrm{~S}_{2} \mathrm{O}_{4}(\mathrm{MW}=710.30)$ : calculated (found) C, 60.87 (61.32); H, 4.25 (4.24); N, 7.88 (7.93); S, 9.02 (9.88). IR (ATR) $\left(\mathrm{v}_{\max } / \mathrm{cm}^{-1}\right): 1611 \mathrm{v}(\mathrm{C}=\mathrm{C})_{\mathrm{py}}+\mathrm{v}(\mathrm{C}=\mathrm{N})_{\mathrm{py}} ; 1288 \mathrm{v}_{\mathrm{asym}}\left(\mathrm{SO}_{2}\right) ; 1144 \mathrm{v}_{\text {sym }}\left(\mathrm{SO}_{2}\right) ; 966$ $\mathrm{v}(\mathrm{S}-\mathrm{N})$. $\mathrm{ESI}^{+}$(DMF): $\mathrm{m} / \mathrm{z}^{+} 732.1\left[\mathrm{Cu}(\mathrm{L} 1)_{2}+\mathrm{Na}\right]^{+} ; 748.1\left[\mathrm{Cu}(\mathrm{L} 1)_{2}+\mathrm{K}\right]^{+}$. Solid UV-Vis $\left(\lambda_{\max } / \mathrm{nm}\right): 400 ; 595$. UV-Vis (DMF) $\left(\lambda_{\max } / \mathrm{nm}\right): 625$.

\section{Synthesis of complex [Cu(L2)]n}

$1 \mathrm{mmol}(199.65 \mathrm{mg})$ of solid $\mathrm{Cu}\left(\mathrm{CH}_{3} \mathrm{COO}\right)_{2} \cdot \mathrm{H}_{2} \mathrm{O}$ was added to a solution of $1 \mathrm{mmol}(494.59 \mathrm{mg}) \mathrm{H}_{2} \mathrm{~L} 2$ in $30 \mathrm{~mL}$ DMF. The resulting darkgreen solution was stirred for $1 \mathrm{~h}$ and left to stand at room temperature. Green plate monocrystals suitable for $\mathrm{X}$-ray diffraction formed in the reaction mixture after $24 \mathrm{~h}$. The crystals were isolated by means of filtration, washed with methanol and dried under vacuum.

Data for $[\mathrm{Cu}(\mathrm{L} 2)]_{\mathrm{n}}$ - Anal. for $\mathrm{CuC}_{24} \mathrm{H}_{20} \mathrm{~N}_{4} \mathrm{~S}_{2} \mathrm{O}_{4}(\mathrm{MW}=556.10)$ : calculated (found) C, 51.83 (51.34); H, 3.62 (3.97); N, 10.07 (10.99); S, 11.53 (10.40). IR (ATR) $\left(\mathrm{v}_{\mathrm{max}} / \mathrm{cm}^{-1}\right): 1666 \mathrm{v}(\mathrm{C}=\mathrm{C})_{\mathrm{py}}+\mathrm{v}(\mathrm{C}=\mathrm{N})_{\mathrm{py}} ; 1277 \mathrm{~V}_{\mathrm{asym}}\left(\mathrm{SO}_{2}\right)$; $1144 \mathrm{v}_{\text {sym }}\left(\mathrm{SO}_{2}\right) ; 966 \mathrm{v}(\mathrm{S}-\mathrm{N})$. Solid UV-Vis $\left(\lambda_{\max } / \mathrm{nm}\right): 400 ; 615$. 
ANDREEA BODOKI, GLORIA ALZUET-PIÑA, JOAQUÍN BORRÁS, TAMARA TOPALĂ, ADRIANA HANGAN, GHEORGHE BORODI, LUMINIȚA OPREAN

\section{X-ray data collection and structure refinement}

Crystal data, experimental details and refinement results are listed in Table 3 Crystal data were collected at room temperature, using a dual microsource SuperNova diffractometer ( $50 \mathrm{kV}$ and $0.8 \mathrm{~mA})$ equipped with Eos CCD detector using CuKa radiation. The data were processed with OLEX2 [42] and the structures were solved with SHELXS [43] using direct methods and refined with SHELXL [44] refinement package using Least Square minimization. Molecular graphics were made with program MERCURY [45].

Table 3. Crystal data and structure refinement for complexes $\left[\mathrm{Cu}(\mathrm{L} 1)_{2}\right]$ and $[\mathrm{Cu}(\mathrm{L} 2)]_{\mathrm{n}}$

\begin{tabular}{|c|c|c|}
\hline Complex & {$\left[\mathrm{Cu}(\mathrm{L} 1)_{2}\right]$} & {$[\mathrm{Cu}(\mathrm{L} 2)]_{\mathrm{n}}$} \\
\hline Empirical formula & $\mathrm{C}_{36} \mathrm{H}_{30} \mathrm{CuN}_{4} \mathrm{O}_{4} \mathrm{~S}_{2}$ & $\mathrm{C}_{24} \mathrm{H}_{20} \mathrm{CuN}_{4} \mathrm{O}_{4} \mathrm{~S}_{2}$ \\
\hline Formula weight & 710.30 & 556.11 \\
\hline Temperature (K) & 293(2) K & $293(2) \mathrm{K}$ \\
\hline Wavelength $(\hat{A})$ & 1.54184 & 1.54184 \\
\hline Crystal system, space group & Monoclinic, P21/n (No. 14) & Monoclinic, C 2/c (No. 15) \\
\hline$a[\AA]$ & $13.9874(2)$ & $10.7500(8)$ \\
\hline $\mathrm{b}[\AA]$ & $7.85430(10)$ & 20.734(8) \\
\hline$c[\AA]$ & $29.1957(4)$ & $15.0045(7)$ \\
\hline$\alpha\left[^{\circ}\right]$ & 90 & 90 \\
\hline$\beta\left[{ }^{\circ}\right]$ & $90.0060(10)$ & $98.467(7)$ \\
\hline $\mathrm{Y}\left[{ }^{\circ}\right]$ & 90 & 90 \\
\hline Volume $\left[\AA^{3}\right]$ & $3207.48(8)$ & $3307.8(5)$ \\
\hline $\mathrm{Z}$, calculated density $\left[\mathrm{mg} \mathrm{m}^{-3}\right]$ & $4,1.471$ & $8,1.149$ \\
\hline Absorption coefficient $\left[\mathrm{mm}^{-1}\right]$ & 2.566 & 2.393 \\
\hline$F(000)$ & 1468 & 1172 \\
\hline Crystal size [mm] & $0.40 \times 0.20 \times 0.01$ & $0.08 \times 0.08 \times 0.02$ \\
\hline$\theta$ range for data collection $\left[^{\circ}\right]$ & 6.054 to 141.252 & 8.53 to 140.2 \\
\hline Limiting indices & $\begin{array}{l}-16 \leq h \leq 17, \\
-6 \leq k \leq 9, \\
-33 \leq 1 \leq 35\end{array}$ & $\begin{array}{l}-11 \leq h \leq 12 \\
-18 \leq k \leq 25 \\
-13 \leq I \leq 18\end{array}$ \\
\hline Reflections collected/unique & $\begin{array}{l}22555 / 6084 \\
{[R(\text { int })=0.0429]}\end{array}$ & $\begin{array}{l}6108 / 2498 \\
{[R(\text { int })=0.0343]}\end{array}$ \\
\hline Data/restraints/parameters & $6084 / 0$ / 424 & $2498 / 0 / 164$ \\
\hline Final $R$ indices $[I>2 \sigma(I)]$ & $\mathrm{R} 1=0.0427, \mathrm{wR} 2=0.1152$ & $R 1=0.1231, w R 2=0.3097$ \\
\hline $\mathrm{R}$ indices (all data) & $\mathrm{R} 1=0.0526, \mathrm{wR} 2=0.1261$ & $R 1=0.1804, w R 2=0.3762$ \\
\hline
\end{tabular}


COPPER(II) COMPLEXES WITH NEW N-SUBSTITUTED SULFONAMIDES - SYNTHESIS, CRYSTAL STRUCTURE AND EVALUATION OF THE NUCLEASE ACTIVITY

\section{pUC18 DNA cleavage}

The nuclease activity of complex $\left[\mathrm{Cu}(\mathrm{L} 1)_{2}\right]$ and $\mathrm{Cu}_{2}(\mathrm{~N}$-(pyridin-2yl)biphenyl-4-sulfonamidate) $)_{4}$ was evaluated by means of gel electrophoresis in the presence of a sodium ascorbate as activating agent. Reactions were performed by mixing $7 \mu \mathrm{L}$ of $0.05 \mathrm{M}$ borate buffer $(\mathrm{pH} 8.0), 0.5 \mu \mathrm{L}$ of $\mathrm{pUC18}$ $(0.5 \mu \mathrm{g} / \mu \mathrm{L}$, Thermo Scientific), $6 \mu \mathrm{L}$ of a solution of the tested complex at increasing final concentrations between $3 \mu \mathrm{M}$ and $12 \mu \mathrm{M}$, and $6 \mu \mathrm{L}$ of ascorbate. All final mixtures employed for DNA cleavage evaluation contained $5 \%$ DMF. The mixtures were allowed to stand for $1 \mathrm{~h}$ at $37^{\circ} \mathrm{C}$. After that, $3 \mu \mathrm{L}$ of a quench buffer solution consisting of $0.25 \%$ bromophenole blue, $0.25 \%$ xylene cyanole, and $30 \%$ glycerol was added. The solution was then subjected to electrophoresis on a $0.8 \%$ agarose gel in $0.5 \times$ TBE buffer $(0.045 \mathrm{M}$ tris, $0.045 \mathrm{M}$ boric acid, and $1 \mathrm{mM}$ EDTA) containing $2 \mu \mathrm{L} / 100 \mathrm{~mL}$ of a solution of ethidium bromide $(10 \mathrm{mg} / \mathrm{mL})$ at $80 \mathrm{~V}$ for $2 \mathrm{~h}$. The gel was photographed on a capturing gel printer plus TDI.

\section{Supplementary data}

The crystals have been deposited at The Cambridge Crystallographic Data Centre and have been assigned the following deposition numbers: CCDC 1973146 for [Cu(L1) 2] and CCDC 1973145 for [Cu(L2)]n.

\section{ACKNOWLEDGEMENTS}

We thank Malva Liu-González (University of Valencia) for assistance with the X-ray data analysis of compounds $\left[\mathrm{Cu}(\mathrm{L} 1)_{2}\right]$ and $[\mathrm{Cu}(\mathrm{L} 2)] \mathrm{n}$.

\section{REFERENCES}

1. Z. Yu; J. A. Cowan; Curr. Opin. in Chem. Biol., 2018, 43, 37-42

2. B. Dey; S. Thukral; S. Krishnan; M. Chakrobarty; S. Gupta; C. Manghani; V. Rani; Mol. Cell. Biochem., 2012, 365, 279-299

3. Z. Yang; N. E. Price; K. M. Johnson; Y. Wang; K. S. Gates; Nucleic Acids Res., 2017, 45, 6275-6283

4. K. Mjos; C. Orvig; Chem Rev., 2014, 114, 4540-4563

5. Z. Yu; J. A. Cowan; Angew. Chem. Int. Ed., 2017, 56, 2763-2766

6. R. Salvio; S. Volpi; R. Cacciapaglia; F. Sansone; L. Mandolini; A. Casnati; The Journal of Organic Chemistry, 2016, 81, 4728-4735 
ANDREEA BODOKI, GLORIA ALZUET-PIÑA, JOAQUÍN BORRÁS, TAMARA TOPALĂ, ADRIANA HANGAN, GHEORGHE BORODI, LUMINITTA OPREAN

7. M. Soler; E. Figueras; J. Serrano-Plana; M. González-Bártulos; A. Massaguer; A. Company; M. A. Martínez; J. Malina; V. Brabec; L. Feliu; M. Planas; X. Ribas, M. Costas; Inorg. Chem., 2015, 54,10542-10558

8. A. M. Pisoschi; A. Pop; Eur. J. Med. Chem., 2015, 97, 55-74

9. C. Santini; M. Pellei; V. Gandin; M. Porchia; F. Tisato; C. Marzano; Chem Rev., 2014, 114:815-862

10. N. Hadjiliadis; E. Sletten; Metal Complex-DNA Interactions. John Wiley \& Sons, New York, 2009

11. T. H. Maren; C.W. Conroy; J. Biol. Chem., 1993, 268, 26233-26239

12. A. K. Ghosh; L. M. Swanson; H. Cho; S. Leshchenko; K. A. Hussain; S. Kay; D. E. Walters; Y. Koh; H. Mitsuya; J. Med. Chem., 2005, 48, 3576-3585

13. A. Scozzafava; T. Owa; A. Mastrolorenzo; C. Supuran; Curr. Med. Chem., 2003, 10, 925-953

14. F. Zhong; G. Geng; B. Chen; T. Pan; Q. Li; H. Zhang; C. Bai; Org. Biomol. Chem., 2015, 13, 1792-1799

15. J. L. Garcia-Gimenez; J. Hernandez-Gil; A. Martinez-Ruiz; A. Castineiras; M. Liu-Gonzalez; F. V. Pallardo; J. Borras; G. Alzuet Pina; J. Inorg. Biochem., 2013, $121,167-178$

16. M. González-Álvarez; A. Pascual-Álvarez; L. del Castillo Agudo; A. Castiñeiras; M. Liu-González; J. Borrás; G. Alzuet-Piña; Dalton Trans., 2013, 42, 1024410259

17. J. L. García-Giménez, M. González-Álvarez; M. Liu-González, B. Macías; J. Borrás, G. Alzuet; J. Inorg. Biochem., 2009, 103, 923-934

18. A. Bodoki; A. Hangan; L. Oprean; G. Alzuet; A. Castiñeiras; J. Borrás J; Polyhedron, 2009, 28, 2537-2544

19. A. Bodoki; A. Hangan; L. Oprean; A. Castiñeiras; J. Borrás; M. Bojita; Farmacia, 2008, 6, 607-614

20. A. Pascual-Álvarez; T. Topala; F. Estevan; F. Sanz; G. Alzuet-Piña; Eur. J. Inorg. Chem., 2016, 2016, 982-994

21. A. Hangan; R. Stan; A. Turza; L. Oprean, E. Pall, S. Gherorghe-Cetean; B. Sevastre; Trans. Met. Chem., 2017, 42, 153-164

22. A. Hangan; A. Turza; R. Stan; B. Sevastre, E. Pall; S. Cetean; L. Oprean; J. Chem. Sci., 2016, 128, 815-824

23. T. Topala; A. Pascual-Álvarez; M.A. Moldes-Tolosa; A. Bodoki A; A. Castiñeiras; J. Torres; C. del Pozo, J. Borrás; G. Alzuet-Piña; J. Inorg. Biochem., 2020, 202, 110823. doi:https://doi.org/10.1016/j.jinorgbio.2019.110823

24. A. Bodoki; G. Alzuet, A. Hangan; L. Oprean; F. Estevan, A. Castiñeiras; J. Borrás; Inorg. Chim. Acta, 2010, 363, 3139-3144

25. L. P. Battaglia; A. B. Corradi; G. Marcotrigiano; L. Menabue; G. C. Pellacani; Inorg. Chem., 1979, 18, 148-152

26. L Yang; D. Powell; R. Houser; Dalton Trans., 2007, 9, 955-964

27. B. Macias; M. V. Villa; M. Salgado; J. Borras; M. Gonzalez-Alvarez; F. Sanz; Inorg. Chim. Acta, 2006, 359, 1465-1472

28. M. Barquín; M. J. González Garmendia; L. Larrínaga; E. Pinilla; M.R. Torres; Inorg. Chim. Acta, 2009, 362, 2334-2340 
COPPER(II) COMPLEXES WITH NEW N-SUBSTITUTED SULFONAMIDES - SYNTHESIS, CRYSTAL STRUCTURE AND EVALUATION OF THE NUCLEASE ACTIVITY

29. L. Gutierrez; G Alzuet; J. Borrás; M. Liu-González; F. Sanz; A. Castiñeiras; Polyhedron 2001, 20, 703-709

30. J. Casanova; G. Alzuet; J. Latorre; J. Borras; Inorg. Chem., 1997, 36, 20522058

31. J. Casanova; G. Alzuet; S. Ferrer; J. Latorre, J. A. Ramirez; J. Borras; Inorg. Chim. Acta, 2000, 304,170-177

32. S. T. Frey; H. H. J. Sun; N. N. Murthy; K. D. Karlin; Inorg. Chim. Acta, 1996, 242, 329-338

33. J. L. García-Giménez; G. Alzuet; M. González-Álvarez; A. Castiñeiras; M. LiuGonzález; J. Borrás; Inorg. Chem., 2007, 46, 7178-7188

34. G. Alzuet, J. A. Real; J. Borrás' R. Santiago-García; S. García-Granda; Inorg. Chem., 2001, 40, 2420-2423

35. C. Janiak; J. Chem. Soc., Dalton Trans., 2000, 21, 3885-3896

36. B. Macias, M. Villa; M. Salgado; J. Borras; M. Gonzalez-Alvarez; F. Sanz; Inorg. Chim. Acta, 2006, 359, 1465-1472

37. WINEPR Simfonia 1.25, Bruker Analytik GmbH, Karlsruhe, FRG, 1994

38. M. F. El-Shazly; A. El-Dissowky; T. Salem; M. Osman; Inorg. Chim. Acta, 1980, $40,1-6$

39. Y. Zhao; J. Zhu; W. He; Z. Yang; Y. Zhu; Y. Li; J. Zhang; Z. Guo; Chem.: Eur. J., 2006, 12, 6621-6629

40. K. J. Humphreys; K. D. Karlin; S. E. Rokita; J. Am. Chem. Soc., 2002, 124, 8055-8066

41. A. Eskandari; J. N. Boodram; P. B. Cressey; C. Lu; P. M. Bruno; M. T. Hemann; K. Suntharalingam; Dalton Trans., 2016, 45, 17867-17873

42. O. Dolomanov; L. Bourhis; R. Gildea; J. Howard; H. Puschmann; J. Appl. Crystallogr., 2009, 42, 339-341

43. G. Sheldrick; Acta Crystallogr., 2008, A64, 112-122

44. G. Sheldrick; Acta Crystallogr., 2015, C71, 3-8

45. C. F. Macrae; I. J. Bruno; J. A. Chisholm; P. R. Edgington; P. McCabe, E.Pidcock; L. Rodriguez-Monge, R.Taylor; J. van de Streek; P. A. Wood; J. Appl. Crystallogr., 2008, 41, 466-470 
